\title{
Faith, Reason and Statecraft in Contemporary Islam: Interpretations, Interface and Distortions
}

\section{Muhammad Feyyaz}

\begin{abstract}
Role of reason in faith and statecraft in Islam is the central feature that this article attempts to investigate. The underlying argument that constitutes the premise of the paper is the suggestion that faith and reason are mutually amenable, and their sustained bondage is essential for forward movement of the state, its citizenry and the statecraft. A key question being looked at is whether or not intellectual movement in Islam is experiencing stagnation or otherwise. Following a systematic enquiry pathway, the discourse therefore examines how, to what extent, and for how long reason has guided development of Islamic jurisprudence and political thought with contingent bearing upon direction of the state and statecraft until contemporary Muslim environment. Among others, the discussion engages with controversies surrounding ijtihad as well as the question of Islam versus modernity with necessary reference to secularism. The paper concludes by resolving the issues raised.
\end{abstract}

Keywords: Ijtihad, Statecraft, Modernity, Muslim Society, Intuition

\section{Why this Discourse?}

Religious and anti-religious people alike habitually ask about reason - faith linkage from time to time, partly because it has a deceptively simple meaning and partly because, although as it stands, it is a vague question, it nevertheless refers to something of vital, burning importance with which every believer, in every religious tradition, has to come to terms with over the course of his religious life. ${ }^{1}$ At this historical juncture, when much of the Muslim world is in a state of disarray, and when there appears to be no clear vision as to where it stands, what determining role its faith should play, and what, as a community of God (Umma), is the horizon of its action and position among nations, contemplation on faith-reason correlation within the framework of state becomes exceedingly important. ${ }^{2}$ Substantive understanding of this project however implores clarity on relative position of faith by turning toward sources of all knowledge begetting it - reason, intuition and authority.

Each of these variables has its distinct etymology, and operates in own epistemological domain. Intuition relates to conviction of certainty (yaqeen) of an impending occurrence. The word referred to as a higher kind of intellect is derived from a verb that means 'looking at', and its extended use seems to have originated as a metaphor from sight. ${ }^{3}$ Arguably, it principally resides in abstract firmness of faith which positions it beyond the realm of rationalism. In Iqbal's philosophy, great emphasis has been laid on intuition as a

\footnotetext{
1 Aziz Esmail, "Reason and Religion: The Old Argument Revisited," Institute of Ismaili Studies 2003, accessed 26 September 2013, http://www.iis.ac.uk/SiteAssets/pdf/esmail_reason_religion.pdf

2 Amr G. E. Sabet, Islam and the Political Theory, Governance and International Relations (London: Pluto Press, 2008), 5.

3 Stocks, J. L.,"Reason and Intuition", in Reason and Intuition and Other Essays (London, 1939), 3.
} 
mode of knowledge. He therefore rejects reason which does not recognize intuitions. ${ }^{4}$ This thinking accords with those who "say we believe in God because our intuitions about how and why things happen lead us to see a divine purpose behind ordinary events that don't have obvious human causes." 5

Within temporal spheres, it has been posited that "Intuition may have an important role in finding answers to all sorts of problems in everyday life." ${ }^{6}$ In this sense, its primary anchor is rooted more in experiential backdrop. Among others, General MacArthur's decision to undertake Inchon landing during the Korean war of the 1950s amidst height of tidal forecasting exemplifies the role of intuition in decision making of strategic consequences. Despite its psychological appeal, value of intuition as an instrument to seek guidance is confined to those who are aware of its spinoff or those who receive it as a strong forewarning impulse.

On the other hand, authority as a source of knowledge is a function of social setting drawing upon historical narratives. This syndrome prevalent mostly in social institutions is inspired by belief in ancestral authority which generates a faith framework with less reliance on reason. ${ }^{7}$ It hardens overtime along kinship lineage and becomes less receptive to logic due to resistance by the authoritative guardians to change. In many ways, authority can also be understood as a form of institutional memory, feeding on past mechanisms, processes and exclusive interactions. Conceptually, this phenomenon can be conflated with taqleedi (adherence, 'blind imitation', literalism, also 'uncritical faith') traditions.

Broadly, and as it emerges from the above discussion, both intuition and authority contain germs of aversion to reason, and warrant stringent scrutiny before being trusted. Besides, their role increasingly centers in nonformal and individualistic spheres than in systemic complexities surrounding statecraft. Exceptions symbolized in initiative by MacArthur are episodic and occasional. Yet, conceding their significance and interplay with sociopolitical vagaries, reason qualitatively predominates them vis-à-vis faith due to its impressional allure that seeks rationale justification for all human experience.

On the comparison scale, the given perspective proposes; first, faith and reason have relatively more mutual amenability, and secondly, their sustained bondage is essential for forward movement of the state and its citizenry. Consequently, they turn into essentializing features for a structured, morally just and adaptable statecraft. This tentative suggestion constitutes the underlying premise of this paper. In its breadth, the discussion will inevitably engage with controversies surrounding ijtihad (exertion, striving $)^{8}$ as well as Islam versus modernity question to deduce their comprehensive place vis-à-vis the argument raised. Secularism will figure out prominently in this

\footnotetext{
${ }^{4}$ Muhammad Iqbal, The Reconstruction of Religious Thought in Islam, ed. M.Saeed Sheikh (Lahore: Institute of Islamic Culture, 1996), 1-22; Muhammad Iqbal, Zarbe-e-Kaleem (Lahore: Iqbal Academy Pakistan, n.d.), phalsipha -37 .

5 Stephanie Pappas, "Belief in God Boils Down to a Gut Feeling", Live Science 21 September 2011, accessed 26 September 2013.

6 "Study Suggests Why Gut Instincts Work, "Live Science 8 February 2009.

${ }^{7}$ Muhammad Feyyaz, "Radicalisation in Pakistan," unpublished paper 2013.

${ }^{8}$ Ijtihad is the exertion of mental energy in the search for a legal opinion to the extent that the faculties of the jurist become incapable of further effort. In other words, ijtihad is the maximum effort expended by the jurist to master and apply the principles and rules of usuil alfiqh (legal theory) for the purpose of discovering God's law. For details see Wael B. Hallaq, WAS THE GATE OF IJTIHAD CLOSED? Int. J. Middle East Stud. 16 (1984), 3-41 printed in the United States of America.
} 
discourse. Besides, discussion will also entail among others, attention to conception of state and statecraft in Islam and their transformation in time and space variations reflected in the political thought of the age. The thesis is however, not a philosophical debate on reason or faith. Drawing upon multiple sources, the aim is to investigate and cohere faith-reason interface, their nexus and distortions in order to deepen understanding of the malice plaguing prevailing stagnation of intellectual movement in statecraft (if it is so), and to explore objective pathways reflective of our shared, argumentative and rational faculties to respond to the situation facing the contemporary Muslim world.

Methodologically, the study has employed a blend of qualitative tools albeit without making conspicuous reliance on a single method; historical, case study, discourse, and critique to mention a few. Faith, reason and statecraft are the principal notional frameworks that compose the entire research effort.

\section{Defining Faith, Reason and Statecraft}

Faith has umpteen definitions. A common understanding of faith employed loosely implies perseverance to pursue an ideal. Faith embodied in troika of Unity, Faith and Discipline, as a source of inspiration and a guidance parameter by Quaid-e-Azam Mohammad Ali Jinnah for building the perfect state, highlights this connotation of faith. ${ }^{9}$

Faith is also used interchangeably with religion. According to experts belonging to major religions - Judaism, Christianity and Islam, faith and religion are not the same, but they are inseparably linked together. ${ }^{10}$ In theology, faith has been defined as belief and loyalty to the fundamental sources that provides a value framework of a faith. ${ }^{11}$ The Islamic term for faith is "iman", which has the root meaning of peace. In here, faith emerges as the fountainhead of all actions; it resides in hearts and manifests into actions. ${ }^{12}$ These actions consist, on the one hand, of formal worship that represents relationship with God [which is faith], and on the other, they include all worldly actions that stem from Divine guidance [which is sharia' $h] .^{13}$ A meaningful explanation of the difference between faith and religion is found in Islam: A Concise Introduction by Javed Ahmad Ghamidi. When "worship", in order to fulfill the rights of the relationship between a servant and his Lord, prescribes metaphysical and ethical bases, determines rituals and stipulates limits, then in the terminology of the Qur'ān, this is called "religion" (dīn). Technically, the metaphysical and moral basis of this worship is called al-Hikmah, and the rituals and limits prescribed for it by religion are called al-Kitāb by the Qur'ān. The latter is also called sharīah, which means law. ${ }^{14}$

This is the doctrinal side of religion that has been defined by Professor Alfred Whitehead, an English philosopher, as 'a system of general truths which have the effect of

\footnotetext{
${ }^{9}$ See, Syed Shahjahan Bakhtiyar, "COMMENT: 'Unity, Faith, Discipline', a slogan or a way forward? Daily Times, 22 April 2013.

${ }^{10}$ For detailed discussion read, "Ask the Religion Experts: Is there a difference between faith and religion?" The Ottawa Citizen, Canada 17 January 2013, accessed 26 September 2013, http://www.ottawacitizen.com/life/Religion+Experts+there+difference+between+faith+religion/7833531/stor y.html\#ixzz2WP5a2PVI

${ }^{11}$ As'ad Abukhalil and Farid Esack, "The US, the Muslim World and an Islamic Response," Policy Perspectives 5/1.

12 "Ask the Religion Experts."

${ }^{13}$ Ibid.

${ }^{14}$ Javed Ahmad Ghamidi, Islam: A Concise Introduction 1st Edition trans. Shehzad Saleem (Lahore: Mawrid, 2008).
} 
transforming character when they are sincerely held and vividly apprehended' ${ }^{15}$ In the spiritual domain, Iqbal likens faith with the essence of religion which is more than a feeling but has something like a cognitive content, i.e., the idea which is a vital element in religion. He contends against rival parties - scholastics and mystics, who emphasize on the role of heart (alone) described as the qalb. ${ }^{16}$ For example, Reynold Alleyne Nicholson in The Mystics of Islam, tells that in mystic thought, "the qalb, though connected in some mysterious way with the physical heart, is not a thing of flesh and blood. Unlike the English 'heart', its nature is rather intellectual than emotional, but whereas the intellect cannot gain real knowledge of God, the qalb is capable of knowing the essences of all things, and when illuminated by faith and knowledge reflects the whole content of the divine mind. Hence the Prophet $(S A W)$ said, 'My Earth and My Heaven contain Me not, but the heart of My faithful servant contains Me!" ${ }^{17}$ Faith was defined by the Prophet $(S A W)$ as a belief that is deeply entrenched in one's heart and to which evidence is given by action. ${ }^{18}$ It can be safely surmised from the discussion that religion has a cosmic dimension which is conceptualized as faith, and the doctrinal facet dealing with temporal affairs of individual, state and society in their entirety which is formalized as fiqh or Islamic jurisprudence.

Proceeding further, the reason simply defined is questioning the basis or justification of established foundations governing sociopolitical and religious aspects of human life. In philosophy, reason is constructed as the faculty or process of drawing logical inferences while in theology, reason, as distinguished from faith, is the human intelligence exercised upon religious truth whether by way of discovery or by way of explanation. ${ }^{19}$ A classic debate on reason and faith interface is found in critique of pure reason by Kant that determinates transcendental a priori conditions as a substantially limiting factor on role of reason, thereby providing a legitimate justification to faith, and that of Foucault's postmodern conception of reason by refuting faith. The latter claims that structures, institutions and rationalities of contemporary Western society are informed by human discourse, and reason is the result of historical contingencies and arbitrariness, and hence is not irrational. ${ }^{20}$ His argument is therefore construed as a threat to faith. With reference to significance of contextual dynamics, his observation appears partially plausible when reason is grasped as an agency of change, largely informed by geohistorical contexts of societies. Egypt provides an incisive case study to prove this point where entrenched imperialism during the nineteenth and early twentieth centuries led to phenomenal growth of reason based reform and revival literature. ${ }^{21}$ However, the key argument underlying the problem of faith and reason has been to work out how the authority of faith and the authority of reason interrelate. According to James Swindal, an American Professor of Philosophy, the religious conservatives, traditionalists and biblical philosophers view and defend the world and human life as subject to natural law and

${ }^{15}$ Iqbal, Reconstruction, 1 .

${ }^{16} \mathrm{Ibid}, 12$.

${ }^{17}$ Riffat Hussain, "The Meaning and Role of Intuition in Iqbal's Philosophy," accessed 27 September 2013,

www.allamaiqbal.com.

${ }^{18}$ Arab News Jeddah, Our Dialogue: the Religious Editor, MAS Media Karachi (n.d.), 7.

19 "Encyclopedia Britannica: reason and Rationalism," accessed 26 September 2013 at http://www.britannica.com/EBchecked/topic/493197/reason and http://www.britannica.com/EBchecked/topic/492034/rationalism

${ }^{20}$ Dr. Zulifiqar Ali, "Post-Modern refutation of faith and religion: exploring Foucault's argument," Journal of Islamic Thought and Civilization 2/1 (Spring 2012):

${ }^{21}$ Tareq Y.Ismael and Jacqueline S. Ismael, Government and Politics in Islam (London: Frances Printer (Publishers), 1985), 25-30. 
causal inquiry, wherein humans can intervene in limited ways while the scientific naturalists resolve it on the side of reason (conflict model). ${ }^{22}$ However, a strong compatible model by natural theologians suggests that faith and reason have an organic connection and perhaps even parity. ${ }^{23} \mathrm{He}$ notes that the articles of faith can be demonstrated by reason, either deductively (from widely shared theological premises) or inductively (from common experiences). ${ }^{24}$

A popular perception associated with the religion reason rivalry, especially among Muslim societies is often the use of the expression 'secularism' for non-religiousness (la dinee'at), thereby morphing the construction as secularism vs. religion. In so doing, secularism has been formed into an antireligious narrative albeit controversial. It embraces human reason as the crucial ingredient to inspire its whole spirit expressed in concept, text and practice. For example, the Western worldview that affirms evolution and denies creation, takes a secular view that makes human beings the measure of all things and master of their own destiny, pinning reliance on reason alone, contrary to the argument by Muslim scholars that Islam relies on revelation and reason both to ascertain truths. ${ }^{25}$ It is another thing that in recent years a few religious scientists in the West have claimed a refutation of the main tenets of Darwinian evolution to show that an "intelligent design" rather than the unguided processes of random variation and natural selection that Darwin postulated must be responsible for creating life and human beings. ${ }^{26}$

In response to whether or not to teach Christian doctrine in public schools, the former US President Bush opined that "both sides ought to be properly taught. ${ }^{27}$ That apart, understanding of the essence of secularism in context is essential. It has structural twain, academic (or perceptual) and statist. In the former case, secularism is not understood to imply limitation on religious beliefs; its implication spans across a wide spectrum of applications. In order to accommodate religious diversity in a society, it focuses on pluralism by allowing freedom of adherence to traditions, rituals and practices to all and sundry without being prejudiced to majority considerations of a particular faith or religion. A vivid example of this conception is found in the way Emperor Akbar laid the foundations of secularism and religious neutrality of the state in India. He interpreted secularism as the requirement for the state to be equidistant from different religions with proviso not to treat any religion with special favor. ${ }^{28}$ Sayed Khatab, an Australian Muslim scholar, draws an all together different meaning of secularism opining that secularism does not mean the absence of religion; that is, one who believes in Islamic heritage (i.e., the Qur' an and its commands; shari'ah and its rules) cannot be seen as a secular person. ${ }^{29}$

\footnotetext{
${ }^{22}$ James Swindal, "Faith and Reason," Internet Encyclopedia of Philosophy, accessed 27 September 2013, http://www.iep.utm.edu/faith-re/

${ }^{23}$ Ibid.

${ }^{24}$ Ibid.

${ }^{25}$ Dr. Abdulmomini A.Oba, "Human rights and beyond: some conceptual differences between Islamic and western perspectives of human rights," Journal of Islamic Thought and Civilisation, 2/1 (Fall 2012).

${ }^{26}$ Ronald Dworkin, "Three Questions for America," The New York Review Books, 21 September 2006, http://www.nybooks.com/articles/archives/2006/sep/21/three-questions-for-america/?pagination=false ${ }^{27}$ Ibid.

${ }^{28}$ Amartya Sen, The Idea of Justice (Rawalpindi: Services Book Club, 2010), 37.

${ }^{29}$ Sayed Khatab, The Political Thought of Sayyid Qutb: The theory of Jahiliyyah (London and New York: Routledge 2006), 111.
} 
Within the statist model, religion and state (RAS) dataset is employed to measure whether countries meet several standards of separation of religion and state (SRAS) and secularism-laicism. The SRAS requires that the state neither supports nor hinders any religion while secularist-laicist model specifically declares that not only does the state not support any religion, it also restricts the presence of religion in the public sphere. ${ }^{30}$ Intriguing enough, the analysis finds that the majority of states which declare separationist or secularist-laicist policies in their constitutions do not adhere to these provisions perhaps implying tacit role of religion in politics. Above referred endorsement by Bush advocating study of both evolutionary and intelligent theory perspectives indicates this assertion to an extent. That brings into equation the role of statecraft in public policy arena which came into being soon the existence of state germinated in human history.

Till recent times, more than one hundred and forty-five definitions of state have been put forward by different writers ${ }^{31}$ underscoring complexity in configuring a single definition of statecraft. The challenging issue hence is to assimilate concept of state thoroughly for comprehending meaning and attributes of statecraft subsequently.

The State in occidental idiom is both an idea and a political institution where sovereignty resides in popular will, and every state is sovereign and autonomous against its neighbors. ${ }^{32}$ The term 'state' began to take its present-day significance in the seventeenth century in Europe, historians dating it from the treaty of Westphalia in 1648. Its most essential feature in the modern world is that of a governing entity that legislates, i.e., creates laws, and most usually in our contemporary situation through some form of process of representative democracy. ${ }^{33}$ On the other hand, a critical review of Islamic history and Muslim literature reveals an ambiguous idea of state among major streams of belief. Besides, state and government are often used interchangeably. In Shia theology, e.g., need for a government is driven by the fundamental reason to guarantee the implementation of laws at all levels of society. ${ }^{34}$ This view is inspired by the argument that Islam regards it absurd and unrealistic to say that society is needless of government and brute force even when it possesses sound training, knowledge of law and what is beneficial and harmful. Two verses of the Qur'an are cited to justify the requirement for a government. First, in the verses about the creation of Hadhrat Adam ('a) (Surah alBaqarah 2:30, cited below), the creation of man has been explained in such a manner that his weakness and possibility of going astray is clearly indicated:

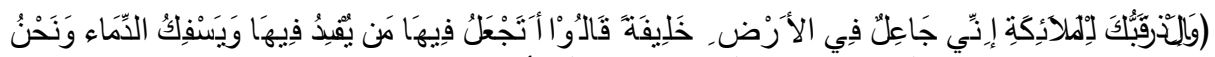

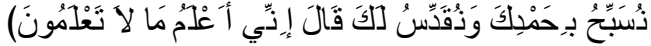

"When your Lord said to the angels, 'Indeed I am going to set a viceroy on the earth,' they said, 'Will you set in it someone who will cause corruption in it, and shed blood,

\footnotetext{
${ }^{30}$ Jonathan Fox, "Separation of Religion and State and Secularism in Theory and in Practice," Religion, State and Society 39:4 (2011):384-401.

${ }^{31}$ Mahmood Ahmad Ghazi, State and Legislation in Islam (Islamabad: Publisher Sharia Academy International Islamic University, 2006), 3.

${ }^{32}$ Ari Afilalo and Dennis Patterson, "Statecraft, Trade and the Order of States," Chicago Journal of International Law 6/ 2 (Winter 2006): 725-759.

${ }^{33}$ Abdassamad Clarke, "The Falsity of the Concept of the Islamic State," BW, http://www.bogvaerker.dk/Bookwright/state.html\#note-17fd0550.

${ }^{34}$ Ayatullah Professor Muhammad Taqi Misbah Yazdi, Islamic Political Theory (Statecraft) Volume 2 (Iran: The Ahl al-Bayt ('a) World Assembly (ABWA), 2006).
} 
while we celebrate Your praise and proclaim Your sanctity?' He said, 'Indeed I know what you do not know'."

The second verse (Surah Ibrahim 14:34, cited below) wherein God describes man as "zalum" which is the superlative degree [Sighah al-Mubalighah] and means "most unfair", indicates that inequity, insolence and ungratefulness in human beings is such that it cannot be neglected, and human societies will always be replete with injustice and ingratitude, signifying the exigency of state and government.

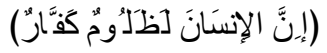

"Indeed man is most unfair and ungrateful!"

In it organic entirety, the approach proposes a theory of state and governance, which later assimilated concepts of asabiyya (natural social solidarity), and Wilayat al-Faqih. ${ }^{35}$ The latter forms the central axis of contemporary Shi'a political thought, and advocates a guardianship-based political system which relies upon a just and capable jurist (faqih) to assume the leadership of the government in the absence of an infallible Imam. ${ }^{36}$ The Supreme Leader (Ayatollah Ali Hosseini Khamenei) in Iran who is constitutionally responsible for the delineation and supervision of "the general policies of the Islamic Republic," and sets the tone and direction of Iran's domestic and foreign policies (statecraft), symbolizes this conceptual underpinning. ${ }^{37} \mathrm{Ibn}$ Khaldun, a historian and architect of sociology, ventures into discussion of governmentality ("governing the self" as well as "governing others") dimension of state with disposition toward assabiyya as the unmitigated power. Khomeini's political theory of al-Wilayat integrates Ibn Khaldun's asabiyya to signify ethnic as well as communal attributes of Iranians in particular and twelver shia's globally in general. ${ }^{38}$

According to Sunni political thought, there is no direct reference in the Qur'an to the institution of a state. Even the term 'state,' or its Arabic equivalent 'dawlah,' [or dawla] has never been used in the Qur'an. The word dawlah was used in the early Islamic sources but not in the sense of a 'state.' The term came to mean 'state' much later, in the fourth or fifth centuries of the Muslim era. ${ }^{39}$ The terminology used by the early Muslim jurists for the Islamic state was 'imamah'. There is no word in the hadith literature for 'state' either. ${ }^{40}$ Yet, Hallaq argues the state remains the favored template of the Islamists and the ulama (Muslim clergy). ${ }^{41}$ Besides, narratives related to state have varied interpretations with generations of Muslim scholars. One stream is content with regional or zonal Islamic governance arrangements - nation state, other views it as consequential and yet another school refers to it in the universal sense. These traditions owe their roots to historical, evolutionary and revisionist nature of development of Muslim thought between eighth and fourteenth centuries. Those advocating the first kind exemplify the state of Madina, involving a single community, and later the era of the Caliphate of

\footnotetext{
${ }^{35}$ Sabet, Islam, 14.

${ }^{36}$ Ahmed Vaezi, Shi'a Political Thought - Chapter 2- What is Wilayat al-Faqih? (UK: Islamic Centre of England, 2004), http://www.al-islam.org/shiapoliticalthought.

37 "The Structure of Power in Iran," Iran Chamber Society, http://www.iranchamber.com/government/articles/structure_of_power.php\#sthash.VkzJ4RWJ.dpuf, accessed 3 October 2013.

${ }^{38}$ Sabet, Islam, 14.

${ }^{39}$ Mahomood Ahmad Ghazi, "The Islamic State in the Contemporary International Scenario," Policy Perspectives 4/2.

${ }^{40}$ Clarke, "The Falsity".

${ }^{41}$ Wael B Hallaq, The Impossible State: Islam, Politics, and Modernity's Moral Predicament (New York: Columbia University Press, 2012).
} 
Usman in their defence. They contend that there has never been a single Islamic political entity (united khilafah) but a plurality of caliphates, sultanates and emirates. ${ }^{42}$ Rise of rival caliphates in Cordova (Spain) and Cairo, autonomous Persian and Turkish dynasties consequent to the fall of Baghdad, and Mughals in South Asia, epitomize it. ${ }^{43}$

Paul Kennedy presents a lucid picture of the state of the Muslim world during the sixteenth century, which then comprised of Turks, Safavids, dwindling Mamluk in Egypt, West African Islamic state, and Babur's rise in India, to mention a few. ${ }^{44}$ South eastern archipelago (Indonesia, Malaysia) from middle of the thirteenth century is yet another example of stratification Muslim rule into sultanates. ${ }^{45}$ Going a step further, Noah Feldman claims that to characterise post-khulafe' al-rashiden (guided vicegerents) system of governments as Islamic state, is to do violence to history. There were no Islamic states but states run by Muslims in the name of Islam. ${ }^{46}$ Persian literature known as andarz-namin ('Book of Advice') and Arabic nusha-tul-muluk ('Counsel of Kings') written by Ghazali, Khajah Nasir Tusi and Nizam ul Mulk developed a theory of kingship clearly influenced by pre-Islamic Iranian notions of governments, though dressed in an appropriately Islamic garb, explicates aboriginal character of Islamic states. ${ }^{47}$ Further, the expediency to sustain autonomous structures can be found in the works of jurists who defended tyranny as the lesser of the two evils when the alternative was anarchy. ${ }^{48}$ Identically, in early twentieth century, the idea of Islamic nation state was not only being declared by Turkish secularists but also by Muslims of such diverging outlooks as Abd ar-Raziq, Rashid Rida, al-Hamid bin Badis of Algeria, Abd al-Raziq al-Sunhouri, Hasan al-Banna and Abd al-Qadir of Egypt, Abd al-Rehman al-Bazzaz in Iraq, Alal al-Fasi in Morocco and the 'Ulama' of al-Azhar, many of whom were disposed toward democratic Islamic government. ${ }^{49}$ Interestingly Hasan al-Banna, a religious scholar and founder of present day Muslim Brotherhood, who is sometimes cited as one of the pioneers of global violent Salafia movement ${ }^{50}$ also saw Khilafah as relatively unimportant side issue on the road to Islamic government. ${ }^{51}$

The second stream holds the state a religious obligation to realize ethical and social potential and attendant responsibilities thereof, of the collective Ummah (wider Muslim community), for which political power is essential, and hence need for a state. ${ }^{52}$ Despite being a proponent of the modern state, Abd ar-Raziq admitted that contrary to the

\footnotetext{
${ }^{42}$ Read e.g., Naef R. F. Al-Rodhan, Neo-statecraft and Meta-geopolitics: Reconciliation of Power, Interests and Justice in the 21 st Century (Geneva: Geneva Centre for Security Policy LIT Verlag Münster, 2009), 168171; Abdassamad Clarke, "The Falsity of the Concept of the Islamic State," BW; Hamid Enayat, Modern Islamic Political Thought (Kuala Lumpur: Islamic book trust, 2001), 119.

${ }^{43}$ Hamid Enayat, Modern Islamic Political Thought (Kuala Lumpur: Islamic Book Trust, 2001), 13.

${ }^{44}$ Paul Kennedy, The Rise and Fall of the Great Powers (Rawalpindi: Services Book Club, 1996), 10-11.

${ }^{45}$ Read, Jonathan H. Pinmg, Middle Power Statecraft: Indonesia, Malaysia and the Asia Pacific (UK: Ashgate Publishing, Ltd., 2005), 141-155.

${ }^{46}$ Abdul Rashid Moten, review of The Fall and Rise of the Islamic State, by Noah Feldman, Intellectual Discourse 17/1 (2009): 107-122.

${ }^{47}$ Enayat, Modern, 18.

${ }^{48}$ Ibid.

${ }^{49}$ Ibid, 104. Ismael and S. Ismael, Government, 40.

${ }^{50}$ Anthony Bubalo Greg Fealy, "Joining the Caravan? The Middle East, Islamism and Indonesia," Lowy

Institute Paper 05, 2005, The Lowy Institute for International Policy, Australia, 14.

${ }^{51}$ Ismael and S. Ismael, Government, 42.

${ }^{52}$ For detailed discussion read, Ghazi, State, 6-8 and ibid, "Scenario."
} 
caliphate, the creation of government has in fact been envisaged in Quran as an essential instrument to administer the affairs of the Muslims, and protect their interests. ${ }^{53}$

Finally, the revivalist school driving the global Islamic movement is associated with several religious luminaries and ideologues viz. Imam Taymiyya, Muhammad Ibn Abd al Wahhab, Maulana Abul A'la Maududi, Sayyid Qutb, Mohammad Salam Faraj, Abdullah Youssuf Azzam, Aymen Alzawahiri and Sayyed Iman Al-Sharf (albeit to a lesser degree). For them, and in particular Maududi, an Islamic state has universal meaning since notion of Ummah transcends all races, social distinctions and regions wherein 'humans are defined in terms of vicegerency'- Khilafat. It is for this reason that they reject notions of both ethno centricism and nationalism in an Islamic state due to the narrow interests emerging from race, language, geography and history. ${ }^{54}$ Maududi therefore, abhorred the concept of 'Muslim Nationalism' latent in the Two Nation Theory underpinning creation of Pakistan by All India Muslim League, the party that was called 'chaste prostitute' by him. ${ }^{55}$ His reflection on Islamic state of global dimension can be noticed in a public lecture on 'Jihad in Islam' delivered at Lahore Town Hall in April 1939:

"The purpose of Islam is to set up a state on the basis of its own ideology and programme, regardless of which nation assumes the role of the standard-bearer of Islam or the rule of which nation is undermined in the process of establishment of an ideological Islamic State. Islam requires the earth - not just a portion, but the whole planet - not because the sovereignty over the earth should be wrested from one nation or several nations and vest in one particular nation, but because the entire mankind should benefit from the ideology and welfare programme or what would be truer to say from 'Islam' which is the programme of well-being for all humanity'. Towards this end, Islam wishes to press into service all forces which can bring about such a revolution. ${ }^{, 56}$

In June 1966, Maududi published his critical treatise 'Khilafat-o-Malukiat' (Caliphate and Kingship) encompassing features of an Islamic state inspired by early period of Khilafat and how it transformed later to become perverted monarchies. A distinguishing mark of this book was introspective review of his earlier argument for an Islamic state. Among other characteristics, he envisioned it to be such "an entity predicated on altruism.... whoever of the mankind anywhere on earth wish could embrace its ideals... it will be Islamic in character regardless of its continental proximity...it would face no obstacle if it aspired in becoming a supranational state...but if there are several of these kinds in different parts of the world, all will have Islamic character...if mutually agreed, they could also form a global federation." 57 In addition to conceding to geopolitical realities, the tone and tenor for spread of religious tenets gleaned from this book appear far more disposed in favor of reason and accommodation.

The above discourse supplies some information and peeps into suggestions for statecraft. The concept as such encapsulates and is dependent upon the state as an organizational entity irrespective of its ideological nature, and has been called the 'science of government ${ }^{58}$ Semantically, statecraft assumes its operating character according to the

\footnotetext{
${ }^{53}$ Enayat, Modern, 94.

${ }^{54}$ Tarik Jan, Is Islamic Governance Theocracy? - Pakistan between Secularism and Islam (Islamabad: Institute of Policy Studies, 1998), 119. Also see Khatab, Political, 1.

${ }^{55}$ K.K Aziz, The Murder of History (Lahore: Vanguard Books Pvt Ltd, 1993), 168-170.

${ }^{56}$ For an online Translation read, Abdul Waheed Khan, trans. Jihad in Islam (Lahore: Islamic Publication, (Pvt)

Ltd, n.d.), http://www.scribd.com/doc/18996214/11-Jihad-in-Islam-by-Maududi

${ }^{57}$ Maududi, Khilafat-o-Malukiat Edition 31 (Lahore: Idara Tarjamnaul Quran, 2008 [1966]), 56.

${ }^{58}$ Ping, Middle, 14-15.
} 
purpose and perspective of those employing it, i.e., foreign affairs, economy, trade, security, etc. For example, the common contemporary interpretation of political economists holds it to mean the actions of a state to include both domestic and international actions, and development and implementation of policy. ${ }^{59}$ In the functional sense, it is the application of form of a craft or art that requires skills, technique, and judgment, the use of appropriate policy tools to achieve policy objectives effectively, and always involves deploying power. ${ }^{60}$ Statecraft therefore, embraces all the activities by which statesmen [policy makers, decision making hierarchies, state functionaries, government leaders] strive to protect cherished values and to attain desired objectives visà-vis other nationals and /or international organisations. ${ }^{61}$

A strategic feature of statecraft is its perennial amenability to changes in the nature of the state dictated by shifts in internal as well as external environment. The present scenario where the very nature of the modern state is claimed to have evolved in response to developments unique to the twentieth century, reflects this position. ${ }^{62}$ Significantly, Muslim modernists draw a conceptual parallel to indicate structural resilience of the state by arguing that the whole quest of creating an Islamic form of government [though] must always be in the style of the model of the first Islamic state established at Medina, but not in form rather in higher spiritual purpose of life. ${ }^{63}$ However, systemically statecraft in Islam can be reckoned close to politics that in Arabic is translated as 'siyasa' [or siyasah] which denotes the manner in which a ruler tends and manages his subjects, based on the way that a shepherd tends his flock, which is the primal metaphor of revealed siyasa. ${ }^{64}$ An important aspect that has to be kept in view is that figh which is the domain of jurists and ulama, has not and cannot work in isolation from 'siyasah' (the operation of legal system i.e., statecraft). The structure of an Islamic legal system arises most essentially from the complex interaction of these two institutions - siyasah and ruler on the one hand, and fiqh and the ulama on the other, the indispensability of siyasah cannot therefore be neglected. ${ }^{65}$

\section{Fundamental Muslim Schools and their Traditions}

It will be appropriate here to take a pause in order to trace and explain various Muslim schools in Islamic jurisprudence to establish a frame of reference for subsequent discussion.

The interpretations, interaction and nexus between faith and reason in Islam draw on diverse dialectics involving theological, philosophical and intellectual contests among and between exponents of different strands, i.e., salafi, taqleedi and ijtahadi schools. Each side views construct of Islam and place of reason in it through its held position. Instruments and thresholds of statecraft have been advocated by them accordingly, adopting forms in keeping with local conditions.

\footnotetext{
59 Ibid.

${ }^{60}$ Al-Rodhan, Neo-statecraft, 356.

${ }^{61}$ Ping, Middle, 15.

${ }^{62}$ Afilalo and Patterson, "States."

${ }^{63}$ Sohail Mahmood, The Concept of an Islamic State (Lahore: Progressive Publishers, 1989), 24.

${ }^{64}$ Clarke, "The Falsity".

${ }^{65}$ Frank E. Vogel, "The closing of the door of Ijtihad and application of Law" (paper delivered at the American oriental society conference, Cambridge, Massachusetts, 13 March 199), available at 2http://iepistemology.net/attachments/402_V10N3\%20FALL\%2093\%20-\%20Vogel\%20\%20The\%20Closing\%20Door\%20of\%20Ijtihad.pdf
} 
The proponents of salafism (puritans) besides Quran and Sunnah derive inspiration from aslaf, the 'pious predecessors', the first three generations of Prophet Muhammed's (SAW) followers including his select companions (sahaba) who are seen as paragons for the correct faith and practice of Islam. Salafists are called Ghair Moqalideen (nonadherent of any school) due to accentuation of Tauheediat (oneness of Allah) by discarding all other sources of knowledge. ${ }^{66}$ Salafism, also a method or an approach to Islam, has historically been an effort to revive what are viewed as Islam's fundamentals, and were practiced by as-salaf as-salih (though there is not always agreement between self-described salafists as to what these fundamentals are) ${ }^{67}$ While most revivalists and Islamist movements are salafist to some degree, contemporary salafism is identified with distinct groups that preach a literalist approach to Islam and are largely concerned with reforming the religious practices of individual Muslims. Egypt's salafis and central command of AlQaeda are one of the types constituting part of the current salafist movement. ${ }^{68}$ As a movement, earlier salafiya was distinct from contemporary salafism; most of today's salafists would condemn the older Salafiya as religious innovators. ${ }^{69}$

Even though Imam Ahmad ibn Hanbal, Sheikh ul-Islam Ibn al-Qayyim, Abo al-Hasan Ali ibn Umar al-Daraqutuni and Idn al-Salah are ranked among the leading salafis of their time, salafism assumes its fullest meaning and manifestation in the person of Imam Ibn Taymiyya, who aspired to revive Islam of the Prophet $(S A W)$ and Sahaba that was regarded free of temporal impurities and weird thoughts susceptible to innovations and myths. ${ }^{70}$ There are contrasting views on the use of methods whether by analogy (qiyas) or induction by salafis. Iqbal, Ruth Mas or even Wael Hallaq (tacitly) have opined Taymiyya's tilt towards induction as the only form of reliable argument; others perhaps owing to lack of subtle dimensions of 'Refutation of Logic' by Taymiyya, have assumed him to be an advocate of analogy. ${ }^{71}$

The Salafiya movement, a religious movement dedicated to the puritanical reform of Muslim society in seventeenth, eighteenth and nineteenth centuries in Arabian Peninsula, Yemen, Libya and Sudan was philosophically founded on the work of Ibn Taymiyya. ${ }^{72}$ In South Asia, salafism is identified with Ahle Hadith, who are generally confused with Wahabis, whereas they assert themselves a sub-continental movement vaguely beginning in the eighth century that grounds its tradition into belief of advent of Hadith (sayings of Prophet Muhammad) into this region directly through various sahabas during the life time of the Prophet $(S A W)$. Hence, they are called "Ahle-Hadith" (bearers of the sayings of the Prophet). ${ }^{73}$

Within taqleedi experience, notion of taqleed as such commonly denoted to practices of imitation in pejorative meaning is misleading. Its literal definition and social

\footnotetext{
${ }^{66}$ Muhammad Feyyaz, "Facets of Religious Violence in Pakistan," Counter Terrorist Trends and Analysis 5/2 (2013).

${ }^{67}$ Fealy, "Islamism and Indonesia," xxi.

${ }^{68}$ A brief review on Salafis can be obtained from "What the Salafis Want: An Interview with the Blind Sheik's Son," Time September 2012 by Ashraf Khalil/Cairo

${ }^{69}$ Fealy, "Islamism and Indonesia," xxi.

${ }^{70}$ See Maulana Fazal ur Rehman bin Muhammad Alazhari, Ibn Taymiyya: a Great Reformer (Lahore: Zahid Bashir Press, 2009), 17.

${ }^{71}$ Iqbal, Reconstruction, 102; Ruth Mas, "Qiyas: A Study In Islamic Logic," Folia Orientalia 34 (1998), accessed 3 October 2013, http://spot.colorado.edu/ rmas/MasQiyas1998.pdf; John F. Sowa and Arun K. Majumdar, "Analogical Reasoning," http://www.jfsowa.com/pubs/analog.htm

${ }^{72}$ Ismael and S. Ismael, Government, 25-26.

${ }^{73}$ Feyyaz, "Pakistan."
} 
constructions surpass more than a single formulation. Formatively, it has served as a conceptual tool to examine issues of reality by recourse to injunctions founding other religions and ancient philosophical epistemologies. For example, the Mutazilites applied taqleed equally to both the Islamic and Aristotelian-Neoplatonic traditions, whereas the Ashrites only applied it to the Islamic tradition and not to any other. Besides, taqleed has been deployed as an umbrella idiom to stereotype traditionalists as well as to endorse abiding discursive moral truths, i.e., the rulings or to acclaim teachings of a school of thought or jurist(s) associated with it. It is worth noting that taqleed does not necessarily imply 'blind adherence.' It signifies 'adopting' the rulings of a jurist with trust in their correctness. ${ }^{74}$ In shi'at, taqleed is ranked from simple adherence to Al- marja' or marja iyya (authoritative reference) which is the supreme spiritual source (or Marja`alTaqlid: The Highest Juridical Authority) followed for total commitment in all religious and secular matters. ${ }^{75}$

The first to be identified in Muslim history with taqleedi (traditionalist) characterization were the Ahle hadith ('people of hadith) of eighth century who were primarily concerned with the study of transmitted sources and their literal interpretation, while denying human reason any right to be exercised in ijtihad or in the process of legal reasoning. ${ }^{76}$ Perhaps out of all the empirically recorded traditionalists, they comprised extremists who rejected the strict procedure of qiyas even when based solely on scripture - Hashwis school of Dawud al-Zahiri (d. 270/883). ${ }^{77}$ They disappeared however, in the short term. It is instructive to note that legal theory which entailed the acceptance of qiyas as a source of law, is viewed by Sunnis almost equal in power to the Quran, the Sunna, and the ijma. ${ }^{78}$ Later generations of taqleedi (or mukallideen) mainly in Sunni but also among Shias, were adherents after practices of Hanifi, Maliki, Shafi, Hanbli and Jaffaria (Twelver Shi ite) schools.

Ijtihadi school deriving its inspiration from ijtihad, is a wide embracing identification that includes a whole array of Muslim mujtahids ${ }^{79}$ jurists and scholars who believe in the progressive, dynamic and perennial applicability of Islamic jurisprudence to all ages. It needs clarification that ijtihadi perspective should not be confused with the advocates of Islamic modernism, principally the apologetics, who are attempting to reconcile Islamic theological structure with precepts of the West. Technically, those who considered ijtihad an indispensable ingredient of legal system have been identified as 'people of $r a^{\prime} y^{\prime}$ (who employed qiyas).

\section{Faith, Reason and Statecraft in Islam}

The debate over place and use of reason in Islam is not new, epitomized by Mutazilites and traditionalists spanning either extreme of religious discourse. Schools have differed on role and extent of reason in faith. In addition to that, a sensitive issue that has remained at the center of intellectual probe and warrants prior attention is whether or not the doors of ijtihad are still open, and if yes, how much of it is to be employed in the conduct of state affairs, and if not, what other choices are to be looked upon. That has

\footnotetext{
${ }^{74}$ Dr. Abdulaziz Sachedina, “Taqlid: Blind Adherence or Rational Acceptance?" University of Virginia,

http://people.virginia.edu/ aas/article/article5.htm

${ }^{75}$ Ibid.

${ }^{76}$ Hallaq, The Impossible.

${ }^{77}$ Ibid.

${ }^{78}$ For understanding of these terms see, "Studies in Usul ul Fiqh- Introduction", at http://www-

personal.umd.umich.edu/ etarmoom/

${ }^{79}$ A person entitled to ijtihad is called mujtahid, and a person bound to practice taklid, is called mukallid.
} 
generated assumptions that Islamic law, since it became stagnant at an early period, was usually ignored in practice, and as a result fiqh (Islamic law) retreated into the ideal world of scholarship while the application of law fell under the sway of arbitrary and despotic rulers. Among others, eloquent replies to these questions and idleness of fiqh are found in a study, 'Was The Gate of Ijtihad Closed?' by Wael B. Hallaq published during 1984 and a presentation by Frank Vogal, a law professor at Harvard Law School in 1992. ${ }^{80}$

Before attending to details of these rejoinders, it will be appropriate here to briefly review reason as an attribute of Islam and its learning. The tradition of the use of reason goes back to the Prophet's times. Iqbal observes that the search for rational foundations in Islam may be regarded to have begun with the Prophet himself. His constant prayer was: 'God! grant me knowledge of the ultimate nature of things! ${ }^{81} \mathrm{He}$ goes on, 'inductive reason, which alone makes man master of his environment, is an achievement; and when once born it must be reinforced by inhibiting the growth of other modes of knowledge. Indeed the Quran regards both Anfus (self) and Afaq (world) as sources of Knowledge' [and this] knowledge must begin with the concrete. It is the intellectual capture of and power over the concrete that makes it possible for the intellect of man to pass beyond concrete'. ${ }^{82}$ Amin Ahsan Islahi, a renowned Pakistani scholar of the Quran, while discussing issues of prophetic traditions, comments that one needs to appreciate that the 'Prophet is not expected to defy reason and the fitrah (human nature) for the Faith does not contain any element that violates the fitrah or the human reason'. Therefore, the traditions should be pondered over in the light of the dictates of reason and fitrah. Islahi consequently, insists that the Book of God itself adduces reason and fitrah to prove many of its fundamental premises. ${ }^{83}$

In the same vein but based on a systematic and chronological study of the original legal sources, Hallaq is of the opinion that the views on the history of ijtihad that it was closed after the second/eighth century are entirely baseless and inaccurate ${ }^{84}$ There was no school or a wing of a school inside the Sunni Muslim community that could have opposed ijtihad as a principle. It is true, he argues, that in the third, fourth, and fifth Islamic centuries, ijtihad, the only channel of legal development, was rejected by various elements because of their inimical attitude towards it, such as by Zahiris (and to an extent but later reformed Hanblis). But these groups found no place inside the pale of Sunnism. ${ }^{85}$ It is further revealed that numerous scholars openly disagreed with the established doctrines of the schools during the tenth century. Concomitantly, a heresy goes that in the last three or four decades of the fourth/tenth century, a comprehensive but implicit agreement on the illegality of establishing new schools and of any 'separatist' tendencies was reached approving ijma' (consensus) on the validity of the existing Sunni schools. ${ }^{86}$ To which, Hallaq persuasively demonstrates that nowhere is an explanation found in later centuries until the modern period about the claim of the existence of ijma

\footnotetext{
${ }^{80}$ Vogel, "The closing."

${ }^{81}$ Iqbal, Reconstruction, 2.

${ }^{82}$ Ibid, 101.

${ }^{83}$ Tariq Hashmi, trans., Fundamentals of Hadith Interpretation by Islahi (Mabadi Tadabbur-e Hadith), 11 November 2009.

${ }^{84}$ Hallaq, "Was The Gate of Ijtihad Closed? International Journal of Middle East Studies 16 (1984): 3-41. ${ }^{85}$ Ibid.

${ }^{86}$ Ibid.
} 
on prohibiting the founding of new schools or closing of the gate of ijtihad. He concludes that the gate of ijtihad was never closed in theory nor in practice. ${ }^{87}$

Furthermore, there is no reliable source about the origins, development and the ramifications of closing the gate of ijtihad. ${ }^{88}$ There is one feint narration describing a person Abu Bakr al-Qaffal (one who closes something) who issued a fatwa closing the door of ijtihad in the fourth century of Hijrah/tenth century cited in Islamic Voice in its 138 issue of June 1998 which is not sustained by any evidence; instead it has been refuted as a myth alleging that this strawman is paraded mostly by Wahabis and Hizb al-Tahrir. ${ }^{89}$ The closure has often been taken for granted and history was repeatedly reconstructed upon it. ${ }^{90}$

In theory at least, there is certainly nothing to indicate that ijtihad was put out of practice or abrogated. This is reckoned by uninterrupted practice of the institution of qadi (judge) throughout Muslim history, in almost all regions of their reigns, which buttresses the fact of ijtihad being the root of qada (judgeship) ensuring continuity of the day to day legal system. Vogal notes that the 'closing of the door' (insidad bab al-ijtihad) was intended to constrain rank and file qadis and muftis, not the elite. Elite scholars, who possessed the capabilities and the courage to exercise ijtihad as well as the prestige to make it stick, could breach the barrier exemplified among the late Hanafis. ${ }^{91}$ In addition to commotion over ijtihad, towards the end of the sixth/twelfth century and the beginning of the seventh/thirteenth, another controversy was under juristic spotlight regarding whether or not it is possible for an age to be devoid of mujtahids. One position asserted that the 'gate of judgeship' ( $b a b$ al-qada) was closed because there no longer were any mujtahids. ${ }^{92}$ To which the Hanbalis and a number of prominent Shaf'is maintained, while adducing rational and scriptural evidence, that mujtahids, must exist at all times. An apprehension was expressed however, by the Hanafi's and Shafi's about possible extinction of mujtahids in the short run. ${ }^{93}$

In Shia Islam, descendants from Hadrat Ali and Fatima $(R A)$ are acknowledged as Imams (spiritual leaders) who are beheld as embodying the Prophet's $(S A W)$ authority. Their statements (qawl), acts (fi'l) and approvals (taqr'ir) were considered authoritative like those of the Holy Prophet $(S A W)$, and hence as part of the Sunnah. Accordingly, the Shia did not feel the need for ijtihad contemporaneously with the Sunnis; it was only after the Greater Occultation (al gheybat al-kubra) of the Twelfth Imam (A) that the Shia came to feel the need to practise ijtihad on an extensive scale which has continued ever since.

Structurally, however, ijtihad appreciably differs between Shias and Sunnis. ${ }^{94}$ Shia scholars suggest that as long as the taqlid of the four Sunni Imams is considered binding, and new research, study and expression of views is regarded as impermissible, there

\footnotetext{
${ }^{87}$ Ibid.

${ }^{88}$ Ghulam Nabi Falahi, "Ijtihad - Question of the Controversy Regarding the Closing of the Gate of ijtihad," UK Islamic Mission, http://www.chsbs.cmich.edu/fattah/courses/pols426/ijtihad.pdf

${ }^{89}$ See in a discussion by Sad ibn Abu Waqas regarding Abu al-Hasan al-Karaji "How door of Ijtihad was closed? Islamic Voice 12-06:138 (June 1998/ SAFAR 1419H), Sunniforum, http://www.sunniforum.com/forum/showthread.php?28737-Regarding-Abu-al-Hasan-al-Karaji

${ }^{90}$ Falahi, "ijtihad."

${ }^{91}$ Vogel, "The closing."

${ }^{92}$ Falahi, "ijtihad."

${ }^{93}$ Ibid.

${ }^{94}$ For more details, see Section 4 - The Beginnings of Shi'i Ijtihad, http://www.al-islam.org/altawhid/ijtihad/4.htm
} 
appears to be little hope of any effective change. Shias are of the opinion that the gates of ijtihad were reopened during the eleventh century. The first Shi'i [sic] faqih to open the gates of ijtihad as a comprehensive scientific discipline was Abu Muhammad al-Hasan ibn 'Ali al-'Umiini (d.513/1119), known as Ibn Abi `Aqil, and the first legist to open the gate of practical ijtihad was Shaykh al-Ta'ifah Muhammad ibn al-Hasan al-Tusi (385-460/995-1068), who applied the general principles of jurisprudence to new and emergent furu' (matters). ${ }^{95}$

A contentious issue in administration of juridical judgments among Sunnis has been whether a qadi or jurist belonging to one school can adjudicate a case based on legal formulations from the other, in case he does, shall that render his appointment void or does the ruler have the power to impose jurisdiction of a school upon qadis. Al Mawardi as quoted by Vogel affirms extra school jurisdiction of qadis joined by Hanfis as well who viewed such appointment as legal. The Ottoman rulers however, decreed in later centuries to adhere to dominant Hanfi schools. How temporality and ijtihad are related, finds best explanation in Basri's assertion who regards familiarity with customary law ('urf) as a qualification required for ijtihad, for it is essential, he argues, to determine God's law in the light of the exigencies of human life. ${ }^{96}$ This brings into focus siyasah or statecraft which has remained central to theo-political narratives of Muslim jurists and historians since ages.

Critically reviewed character of statecraft broadly corresponds with two variables, the type of governing dispensation, and its temporal proximity or remoteness from epoch of the Prophet $(S A W)$. The model for statecraft that originated from the state at Medina symbolized justice, equitability, nondiscrimination and communal solidarity (rooted in the mores of pre-Islamic Arabia) for domestic governance, and commitment, honesty, international justice, reconciliation, just treatment of non-hostile forces, and proportionate reprisal for foreign relations. ${ }^{97}$

During the reign of Prophet $(S A W)$, and Khulafa-e-Rashideen, glimpses of these attributes manifest in abundance. Their reign was a period of expansion - to the East, the Persian Empire and Central Asia; to the West, the Byzantine dominions. This period of grace ended with the assassination of Hadrat Ali by a dissident group. ${ }^{98}$ An in-depth study of this phase in Muslin history proves falsification of many misconceptions, writes Barnaby Rogerson in his seminal book - Heirs of the Prophet Muhammad. He disputes the idea of the "Muslim warrior with a sword in one hand and the Quran in another" and forceful conversion to Islam of new subjects, highlighted inter alia, in recognition of Persian Zoroastrianism a "religion of the book" to avoid popular discontent. ${ }^{99}$

While the role of reason vis-à-vis prevailing realities distinguish all of these epic governorships, geopolitics mixed with Arab nationalism and tribal favouritism arising out of divisive trends among Muslims over the question of selection of the caliph, discrimination against the home of the Prophet $(S A W)$ and increasing Iranian intrusion in body politics of Arab from the time of Hadrat Umar, somehow gradually set erosion of

\footnotetext{
${ }^{95}$ Ibid.

${ }^{96}$ Hallaq, "Closed?"

${ }^{97}$ For foreign relations see, Maududi, Khilafat-o-Malukiat, 50-55.

98 Shusha Guppy, "Caliphs of a golden age," review of Heirs of the Prophet Muhammad, by Barnaby Rogerson, the Independent, 19 February 2006, http://www.independent.co.uk/arts-

entertainment/books/reviews/heirs-of-the-prophet-muhammad-by-barnaby-rogerson-525668.html.
99 Ibid.
} 
initial objectives of statecraft idealized by the Prophet $(S A W)$ in motion. ${ }^{100}$ First was the discontent mounted over the favor Hadrat Uthman showed to his own Ummayad family, who seemed to enjoy a monopoly of influential and lucrative appointments. ${ }^{101}$

Despite the challenges confronted by the latter two khulafa (Hadrat Uthman, Hadrat Ali), their states were run by dictates of shariah, and adhered to stipulated limits in exercise of power to maintain rule of law and justice. Later, with the murder of Hadrat Ali, Rogerson broaches, " the era of holiness within the Islamic community is over, the scheming politicians, the police chiefs and the old clan chiefs are once again back in power." Other than semblance of organized administration of state functions during comparatively five larger caliphates, Umayyad, Abbasid, Fatimid, Mamluk and Ottaman, hundreds of dynasties (malukiat) emerged in Asia, Africa, China and parts of Europe, many as offshoots from original caliphates built around Arab-Ajam nationalism and ambition of rulers for self preservation and self perpetuation. Consequently, the statecraft during this period of diverse caliphates, monarchies, emperorships, sultanates and emirates witnessed array of legal and policy instruments. The differentiation chiefly lay in degree of adherence to theological or intellectual school as well as contemporary sociopolitical conditions.

During the times of Malukiat, statecraft has been related to political thought of the age, and therefore drew its direction from it which grew phenomenally during Umayyad, Abbasid, and Ottoman caliphates. Polemical writings spurred by ecclesiastical controversies were one reason to generate and sustain the growth of knowledge including that in non-religious domains. Imam Abu Hamid Al-Ghazali nevertheless, characterized this intellectual difference among the Muslim scholars, thinkers and reformers as crisis in the Ummah's religious culture and thought, and Ummah's philosophical and civilizational culture and thought in his two great works: 'Ihya Ulum ad-Din' and 'Tahafut al-Falasifah' respectively. ${ }^{102}$ Abdul-Hamid Ahmad Abu Sulaiman links genesis of the distortion of the 'Presentational Approach' and its negative impacts when, according to him, men of Al-Madinah School were defeated; firstly, by members of the political elite of the racial and tribalistic Arabs; and later, by the racist non-Arabs resulting in divisive crack and estrangement which led to imposing academic inertia on the intellectual elite. The ideology of practical application, independent judgment, reform and creativity was changed into that of a closed textual ideology which became an ideology that was based on imitation whereby, according to some of them, a weak text that is probably not really authentic was given priority over an opinion based on judgment, and weak text was regarded a proof. ${ }^{103}$ No wonder therefore, that whenever the state [during malukiat] flagged in ideological zeal, the venality of the Ulama filled the vacuum, and the result was always the same; the retreat of critical thought before the encircling rigidity of official dogma. ${ }^{104}$

Nevertheless, a key feature of this period until the sixteenth century, evident from several illuminating theses (e.g., by Hallaq, Ruth, Falahi, etc.) was the sustained attention to

\footnotetext{
${ }^{100}$ Maududi, Khilafat-o-Malukiat, 99-100, 105-116; Enayat, Modern, 46 and W. Montgomery Watt, Islamic Political Thought (UK: Edenburg Univesity Press, 2007), 509.

${ }^{101}$ Richard Cavendish, "Caliph Uthman Murdered," History Today, 56/6 (June 2006), http://wwjw.historytoday.com/archive/history-today/2006/volume-56-issue-6

${ }^{102}$ Abdul-Hamid Ahmad Abu Sulaiman, "Contemporary Islamic Presentational Approach: Distortions,

Confusions and Superficialization," http://i-epistemology.net/.

${ }^{103}$ Ibid.

${ }^{104}$ Enayat, Modern, 18
} 
development of Islamic jurisprudence within classical politico-religious framework accentuated by internal upheavals undergoing in the Muslim world. Europe was yet out of the scene but was the beneficiary of advancement in multidisciplinary spheres of knowledge by Muslim thinkers. Imperialism was to alter this paradigm in later centuries, when the Western discourse at the height of Europe's imperial power came to characterize Islam as inherently "antihumanist", "nonrational", and inimical to modernity ${ }^{105}$ Particularly, the colonial period gave rise to more geographically and politically-oriented forms of Orientalism; anti-Muslim discourse now embraced a new function...the justification of the imperial project, with a corresponding need to show the irrationality, barbarity, obscurantism and backwardness of Muslims and Islam (and therefore their need to be "civilized" and "enlightened"). ${ }^{106}$ It may be noted that it were Christian missionaries who laid the foundation for Orientalism, which reached its peak during the first half of the nineteenth and early twentieth centuries with involvement of missionaries from Belgium, France, Britain, Holland, Spain and the US. They had one objective and that was "to deny and disprove the Prophet's status as such and the Quran as revelation." ${ }^{, 107}$ With the spread of Ottoman Empire into Europe, it was assumed that such an empire stood for the perpetuation of Islamic misrule and tyranny, and such assumptions remained unquestioned for a considerable period during the nineteenth century. ${ }^{108}$ Meanwhile and coincidently, as the emerging West began to check and challenge the power of the Ottoman Empire, effective government administration within the empire was being dissipated by the excesses of luxury and abuses of power.

A corollary of this development was that Muslim consciousness was jolted out of slumber manifested by intensified growth of reform and revival ideologies from the eighteenth century onward, as the foreign powers pushed for strongholds into Muslim territories. Islamic political thought was thus revitalized in Egypt, Iran, Arabia, North Africa and South Asia. ${ }^{109}$ Objectively, among the most authoritative exponents of Islam and the most widely acclaimed interpreters of the Shari'ah from the days of the founders of the major legal schools up to the end of the nineteenth century, none assigned such a central place to the subject of statecraft and politics as is found in the writings of twentieth century revivalist scholars. ${ }^{110}$

The present presentational domain is not only plagued by intra-Muslim polarization, but by non-Muslim world as well where Islam is depicted as a religion of the sword with the blade forever at the throat of the unbeliever. ${ }^{111}$ In the post $9 / 11$ stereotypical representations of Muslims as a community and Islam as a faith, a steep rise was witnessed in psychosocial and political phenomenon as xenophobia in general and Islamophobia in particular. ${ }^{112}$ The analysis of 78 selected articles on how Islam and Muslims are portrayed and represented in the discourses reported in the New York Times newspaper in the wake of the September 11 events and in the ensuing two years, showed

\footnotetext{
${ }^{105}$ Samira Haj, Reconfiguring Islamic Tradition: Reform, Rationality and Modernity (Stanford: Stanford University Press), 189.

${ }^{106}$ Kate Zebiri, "The Redeployment of Orientalist Themes in Contemporary Islamophobia," Studies in Contemporary Islam 10/ 1-2 (2008): 1-41.

${ }^{107}$ Asaf Hussain, "The ideology of Orientalism," in Orientalism, Islam, and Islamists ed. Asaf Hussain, Robert Olson and Jamil Qureshi (Battleboro Vermont: Amana Books, 1984), 7.

${ }^{108}$ Ibid, 6 .

${ }^{109}$ Ismael and S. Ismael, Government, 25-30.

${ }^{110}$ Ghazi, "Scenario."

${ }^{111}$ Timothy R. Furnish, "Beheading in the Name of Islam," Middle East Quarterly (Spring 2005), 51-57.

${ }^{112}$ Muhammad Safeer Awan, "Global terror and rise of xenophobia/Islamophobia: an analysis of American cultural production since September 11,” Islamic Studies 49/4 (winter 2010).
} 
that most of the themes that dominate the representational discourse of Islam and Muslims hover around the concepts of violence, turmoil, threat, jihad, and evilness of Islam and Muslims. ${ }^{113}$ But Islam itself, that is supposed to be the cement of the nation, its raison d'être, is more and more divided. ${ }^{114}$

It has also been asked whether Islam as a system of regulatory beliefs is compatible with the modern world. This question arose in part because Islam has tended to be portrayed as a politicized faith, due to there being no separation between church and state of the type that took place within Christianity. ${ }^{115}$ Consequently, key ideas from modernity are coded to situate Islam in a position where it negates these ideas so that Islam and Muslims are seen as illogical, autocratic, and living in stasis. ${ }^{116}$ Clearly, in such perspectives modernity and tradition are seen as mutually exclusive polar opposites. ${ }^{117}$ This perception primarily stems from democratic norm of precedence or otherwise of contestation between divine and popular will which has been responded varyingly by Muslim intellectuals.

The Islamic concept calls upon the Muslims to subordinate their will and decisions to the guidance of the Divine Law. According to conservatives and traditionalists with this obligation also comes a willing acceptance to adhere to 'all things lawful and permissible by God, unless He himself determines otherwise'. In temporal dimensions, such provision implies that when a government adopts and enforces a law other than that of Islam, then its action amounts to a declaration that it finds that law preferable to, or better than God's law. ${ }^{118}$ Arguing against this doctrinal formulation, Kazem Alamdari, a Muslim scholar on the Middle East, not only declares such a society theocratic but further notes that social regulations that ought to be based on rational, relative, changeable, and collective agreements when based on religious principles, are absolute, unchangeable, and autocratic. ${ }^{119}$ In such a society, he further argues, the government gains its legitimacy not from people's consent but from God's will, freedom of expression is limited and human creativity is repressed. Consequently, the integration of religion and state leads to a centralized and a more absolutist power, and this, in turn, leads to the creation of obstacles to rationalism, secularization, and pluralism for instance, the three fundamental elements of modern civilization in the West. ${ }^{120}$ While endorsing sovereignty of God, Maududi illustrates seven pillars and characteristics of governance by Khulafe-eRashideen - election of khalifa, consultative mechanisms, austerity in use of exchequer, concept of governance, rule of law, uniform equitability and spirit of democracy. ${ }^{121}$ In this lengthy monologue, faith, reason and statecraft have been deconstructed by him as integrated with and into each other to account for monumental changes that were occurring and being experienced in face of the expanding domain of Islam.

\footnotetext{
${ }^{113}$ Murad ali obaid abdullah alazzany, "A critical discourse analysis of the representation of Islam and Muslims following the 9/11 events as reported in the New York Times," University putra Malaysia, November 2008, http://psasir.upm.edu.my/10335/1/FBMK_2008_23_A.pdf

114 Jean-Luc Racine, "Pakistan's predicament: The diagnostic and the debates within,"Journal of Pakistan Vision, 13/1 (2012): 1-30.

${ }_{115}^{115}$ Nasya Bahfen, "Borderless Islam and the modern nation state," Intellectual Discourse 19 (2011): 147-160.

${ }^{116}$ Ibid.

${ }^{117}$ Ibid.

${ }^{118}$ Arab News Jeddah, Our Dialogue, 7.

${ }^{119}$ Kazem Alamdari, "Religion and Development Revisited: Comparing Islam and Christianity with Reference to the Case of Iran," Journal of Developing Societies 20/ 1-2.

${ }^{120}$ Ibid.

${ }^{121}$ Maududi, Khilafat-o-Malukiat, 85-102.
} 
This observation notwithstanding, the religious reductionism and misgovernance challenges confronting Muslim states all over lend credence to critics of real-politik within body politic of Islam supported by numerous indicators. The combined GDP of a billion plus Muslims living in some 56 sovereign Muslim states is less than that of Japan. Barring a few countries like Malaysia and Turkey, most Muslim states are underdeveloped. ${ }^{122}$ One reason for lagging behind in wealth generation is the failure to produce commercial institutions (e.g., joint-stock companies) that distanced themselves from individuals or partnerships and could endure for long periods of time and mobilize large quantities of resources. ${ }^{123}$ Principles such as jihad and martyrdom have introduced new dimensions in politics and conflict in much the same fashion. ${ }^{124}$ Similarly, some experts contend that sectarian populism, the tendency for political leaders to align themselves along sectarian lines as show of solidarity with their constituency, is quickly becoming the dominant factor in Middle Eastern politics and a critical driver of regional instability. ${ }^{125}$

Furthermore, the leadership and legitimacy crises in most Islamic countries are largely a result of the absence of religio-political dialectics as well as by elite capture, internecine power struggles, opportunism and corruption. ${ }^{126}$ In the Corruption Perceptions Index 2012 released by Transparency International, only two out of the 48 Muslim majority countries made it above 50 on the overall ranking with the bottom range overwhelmingly occupied by the remaining. Top six most populated and important Muslim countries (Indonesia, Pakistan, Bangladesh, Nigeria, Iran and Egypt) scored in the miserable range beyond $100 .{ }^{127}$

Above all, offensive/defensive apologia of Muslims is engaged to compensate for repeated attacks on the "authenticity" and the "identity" of the Islamic personality with dogmatic affirmatives and self confirming discourse, reflecting deficiency in indigenous prowess. ${ }^{128}$ Even an erudite scholar like Abu-Sulayman notes that the modern world cannot be explained in terms of the classical concepts and frame of mind. ${ }^{129}$ While a convincing rebuttal by Amr Sabet neutralizes the former by arguing enduring relevance of Islamic theoretical and practical tradition, it does not account for the bigotry among theologians over faith-reason debate on one hand, and insidiousness of secular statecraft practiced by contemporary Muslim leadership for self actualization on the other.

Hallaq makes a compelling case for incoherent statecraft from yet another angle by arguing that the modern [Islamic] state not only suffers from serious legal, political, and constitutional issues, but also, by its very nature, fashions a subject inconsistent with what it means to be, or to live as, a Muslim. ${ }^{130}$ By Islamic standards, the state's

\footnotetext{
122 “Muslim world's condition,” Dawn.com, 5 Dec 2012.

${ }^{123}$ John Draper, "Why are Muslim countries poor? 22 February 2013, http://www.cobourgatheist.com/index.php/islam/muslim-culture/1016-why-are-muslim-countries-poor ${ }^{124}$ Sabet, Islam, 57.

${ }^{125}$ Scott Helfstein, "The Rise of Sectarian Populism," The National Interests 18 July 2013, http://nationalinterest.org/commentary/the-rise-sectarian-populism-8740\#.UgEzTqQRM4s.email ${ }^{126}$ Sabet, Islam, 98

127 Transparency International, “Corruption Perceptions Index 2012,"

http://www.transparency.org/cpi2012/results\#myAnchor1. Also see Dr. Faheem Younus, "Confronting Corruption in the Muslim World," Huff Post - Religion, 16 June 2-11,

http://www.huffingtonpost.com/faheem-younus/enforce-shariah-law-or-le_b_877211.html

${ }^{128}$ Sabet, Islam, 63.

${ }^{129}$ Ibid, 15

${ }^{130}$ Hallaq, The Impossible.
} 
technologies of the self are severely lacking in moral substance, and today's Islamic state, he continues, has done little to advance an acceptable form of genuine Shari'ah governance. The Islamists' constitutional battles in Egypt and Pakistan, the Islamic legal and political failures of the Iranian Revolution, and similar disappointments underscore this fact. ${ }^{131}$

Yet it is also a fact that reason-faith at its optimal level continues to be institutionalized and decreed by leading academia, seminaries, think tanks and educational organizations worldwide in keeping with evolving challenges; Jamia al Azhar in Egypt, Centre for Islamic Research and Studies in Saudi Arabia, The Amman Message Jordan, Islamic universities in Malaysia and Pakistan, judgments by Federal Shariah Court and Council of Islamic Ideology Pakistan and Minhaj ul Quran, Pakistan are a few prominent examples, ${ }^{132}$ in addition to dozens of Islamic studies, academic journals and legal resources operating globally. The establishment of the jurist's governance (wilayat alfaqih) in a modern nation- state of Iran ${ }^{133}$ has also been a novelty of its kind. PostIslamism is the emerging buzzword resonating in intellectual reformation confines, which has been characterized by thinking in some major Islamic religio-political and politicoreligious movements on how to combine Islam with the values of modernity by embracing the idea that modern values are inherent in Islam. ${ }^{134}$

\section{Conclusions}

The discussion has examined faith-reason-statecraft nexus in their definitional, epistemological, and structural dimensions and interactions drawing upon multiple qualitative frames, praxis and indicators. Role of reason was looked at throughout with particular attention. Reference to political thought generated during different times and settings was also probed. Triggers and dynamics impacting change in structural and functional outlook of statecraft in the form of revival and reformation projects was analytically situated accordingly.

At the general plane, the study finds that seventeenth century and early part of eighteenth stand out as devoid of much intellectual activity due to severe tensions and ramification of breakdown of spiritual source of Muslim - Ottoman Khilafat. Prior to and consequent to this monumental shock, development of Islamic jurisprudence and its application has continued. Identically, political thought has moved on though relatively at slow pace between fourteenth and sixteenth centuries, but has not stopped altogether. Demise of Ottoman and colonization were major events that helped revive retarded interest in intellectual and revisionist undertakings. Conquests by Ottoman Turks into hinterland of Europe marked the advent of mutual suspicion of the two largest religious entities of the world. September 11 catastrophe was the pinnacle of historical discord which created constituency of apologetics in the Muslim world. Earlier, modernization reformers were only concerned with integrating Western innovations to improve upon domestic situations. Apologia was non-existent in the literal sense. Misrule, leadership crisis and

\footnotetext{
${ }^{131}$ Ibid.

${ }^{132}$ For details on the Amman Message, visit http://www.ammanmessage.com/; also see Amman Message,

"Islam's Position on Extremism, Radicalism, and Terrorism," Declaration 154, (Jordan: Amman, 2006), 143144; Tahir ul Qadri, Fatwa- Terrorism Fitna- Khawarij, $1^{\text {st }}$ Edition (Lahore: Minhaj Books, Jan 2010).

${ }^{133}$ Sachedina, "Rational Acceptance?

${ }^{134}$ Dr. Laszlo Csicsmann, "Islamist movements at the crossroads: the choice between ideology and contextdriven approach to politic. Case study on the Hashmite kingdom of Jordan," Journal of Islamic Thought and Civilization 1/ 2 (fall 2011): 55-70.
} 
religious infighting indigenous to Islam have harmed Muslim interests more than external incursions. That defines direction of response interventions.

Specifically, it emerges that barring some faint traces of opinions, there is no authentic evidence about non-use of reasoned exertion to extract applications germane to changed environment. The sustained traditions of such endeavors by mechanisms operated by globally known Islamic organizational institutions validate these processes. The fact can be corroborated by size of literature being produced and addicts (fatwas) issued by sharia courts, jurists and seminal academic outfits. A separate study will be required to establish sprawl of this scholarship.

It can be further inferred from the foregoing that closure of ijtihad is merely a metaphor to indicate intellectual crisis in growth of knowledge but otherwise an unsubstantiated myth. Jurists who were capable of ijtihad have existed at nearly all times; ijtihad was used in developing positive law after the formation of the schools; hence, the controversy about the closure of the gate and the extinction of mujtahids prevented jurists from reaching a consensus to that effect.

Some of the mujtahids from the recent past and those alive include Ibn Qayyim AlJawziyya, Ibn Kathir, Muhammad ibn Abd al-Wahhab, Abd al-Aziz ibn Baz, Muhammad ibn al Uthaymeen, Shaikh Muhammad Naasir-ud-deen al-albaani, Maududi, Muhammad Shafi Usmani, and Muhammad Taqi Usmani. Similarly apart from Ayatollah Ali Khamenei, several mujtahids are located in Qum and Najf schools.

It is however, emphasized that faith has to be doctrinally understood as the spiritual ingredient of religion that feeds on and is consolidated by conviction in 'aqeeda' which is reinforced by systematic employment of reason. Critics have therefore described Egyptian reformer Abduh's faith on authority [as source of knowledge] but devoid of contemplative understanding ( $a q l)$ and [inner] discernment (hidaya) as the virtual state of godless rather than one of faith. ${ }^{135}$ The caveat is that Mu'tazilahs's neoplatonical rational that reason is the "final arbiter" in distinguishing right from wrong, and "sacred precedent" is not an effective means of determining what is just, as what is obligatory in religion is only obligatory "by virtue of reason, should not dazzle wisdom. ${ }^{136}$ What needs to be remembered is that inner experience (faith) is only one source of human knowledge. There are two other sources of knowledge according to the Quran - Nature and History; and it is in tapping these sources of knowledge that the spirit of Islam is seen at its best.

${ }^{137}$ This deliberation sufficiently insinuates tradition and space for free enquiry in Islam which has to rely on reason for its actualization to inform public policy processes, institutionalization and implementation in prevailing settings.

It will be in fitness also to objectively conceptualize essence of taqleed. The discourse brings to the fore that while blind imitation is nonsensical, hence may be connoted pejoratively; an informed adherence of a school of thought is healthy. Secondly, while it is common to bifurcate believers into different categories, taqleedi, salfis and ijtihadi, etc. as has been done in this paper as well. Incisively probed, all of them are taqleedi in one form or the other. The differentiation lay in the degree of reliance to pathways or methodologies to find answers to practical problems. Exceptions are there in the person of Ibn Taymiyya who even though a salfi was amenable to all sources of knowledge to

\footnotetext{
${ }^{135}$ Haj, Reconfiguring, 115.

${ }^{136}$ Qussama Arabi, Studies in modern Islamic Law and Jurisprudence (Springer; 1 edition (October 1, 2001).

${ }^{137}$ Iqbal, Reconstruction, 102.
} 
resolve emergent fiqhi issues. ${ }^{138}$ Finally, those who do not believe in ijtihad at all can be classified as orthodox traditionalists.

As to the question of nature of state and statecraft; reality of existing geopolitical configurations constituting nation state system ought to be accepted. This has become now fairly well entrenched in most cases owing to aspired, and fought for ethno nationalistic identities among diverse Muslim societies, not to mention those occurring in intra-Muslim paradigms. This has in turn eroded appeal for a global khilafat which is still subjectively cherished without concrete propositions and models. In intrastate context, Shariah based dispensation is possible. Scholars have opined that [increasingly] misgoverned Muslims yearn for a return to a rule of law, the shariah, "a just legal system, one that administers the law fairly." ${ }^{139}$ Without a genuine desire and consensus among and between politico-religious leadership of concerned states, this will not happen. The misgivings about shariah as a harsh and punitive regime have to be dispelled through articulate national efforts by highlighting its soft facet.

A consultation to these drivers accordingly will shape, organize and animate statecraft to respond to dynamic needs of the state, polity and citizenry. In this respect it is asserted that while element of secularization in itself is not demeaning as long as it is driven by an intent of good, its complete internment to temporality for fulfillment of the 'self' or even the subjects is uncalled for. From this perspective, historical antecedent of Akbar rooted in favour of egalitarian pluralism and centuries later, Aurangzeb Alamgir's reign symbolized by abandoning religious toleration of his predecessors, seem excess of moderation and extreme each at the cost of other. ${ }^{140}$

Whether or not Islam is compatible with modernity is a futile argument. Even though Western writers themselves argue that the idea of modernity and tradition being in contradiction to each other rests on misdiagnosis of tradition as it is found in traditional societies, a misunderstanding of modernity as it is found in modern societies, and a misapprehension of the relationship between them. ${ }^{141}$ This writer would contend that modernization should be viewed from the lens of demand based evolutionary imperatives which is neither opposed by nor opposed to essence of Islam since its inception. The care is essential in adapting practices of modernity which imply marginalization of religion from civil society, state, and politics. ${ }^{142}$ In passing, it may be remembered that modernity has been witnessed by the Muslim world, and in effect was triggered and exported by them to the West. The Muslim quest for knowledge often drove even the most devout rulers and religious scholars to support freethinking and empirical scientific inquiry, this tradition of learning and Islamic education system is believed to have influenced the West. ${ }^{143}$ The notion underlying Akbar's approach, a devout Muslim himself [sic], to social custom and public policy by 'the pursuit of reason' rather than 'the marshy land of

\footnotetext{
${ }^{138}$ See Alazhari, Ibn Taymiyya, 18.

${ }^{139}$ Moten, 189.

${ }^{140}$ See for example, Richard M. Eaton, "Temple Desecration and Indo-Muslim States," under Religions Sikhism: Guru Tegh Bahadur, BBC. 1 October 2009, http://www.bbc.co.uk/religion/religions/sikhism/people/teghbahadur.shtml;

Harbans Mukhia, The Mughals of India. 25-2; Katherine Butler Brown, "Did Aurangzeb Ban Music? Questions for the Historiography of his reign," Modern Asian Studies 41/1:78; John F. Richards, The Mughal Empire, The New Cambridge History of India 5 reprinted edition (UK: Cambridge University Press).

${ }^{141}$ Bahfen, "nation state,"147-160.

${ }^{142}$ Haj, Reconfiguring, 1.

${ }^{143}$ Al-Rodhan, Neo-statecraft, 162-163, 167-171.
} 
tradition' to address difficult problems of good behavior and the challenges of constructing a just society, therefore does not hold ground. ${ }^{144}$ It has been pointed out earlier that both tradition and change can coexist by delineating their respective spheres.

At present, there is no discernable theory of governance and statecraft in contemporary Islamic thought barring contested postulate of wilayat al-faqih which is still in stage of maturation. It is therefore, difficult to identify with precision exact contours of ongoing political thinking in Muslim world other than those emanating from apologetics, and those who have internalized perceptual binaries of clash of civilization. Divisive trends have further weakened voices clamoring for unity. Discussion on post-Islamism is yet in nascent stage.

The budding research needs to engage with questions whether we really require a grand and unified theory and governance in times of fragmentation heightened by impact of globalization, ethnonational assertion, and sectarian nuances, rather than focusing on making living conditions of the general lot worth a respectable life and leave this question for posterity? Or how should a Muslim state define its political identity which predicates itself on cultural pluralism, while its nationals are Muslims and adhere to fundamental tenets of Islam and whether we need to find a novel typology for this purpose to create synergy in faith-reason-statecraft equation to meet challenges of the real world. The subject is wide open for debate and dialogue.

\footnotetext{
${ }^{144}$ Sen, The Idea, 38 .
} 


\section{Selected Bibliography}

1. al-Rodhan, Nayef R. F. Neo-statecraft and Meta-geopolitics: Reconciliation of Power, Interests and Justice in the 21st Century. Geneva: Geneva Centre for Security Policy LIT Verlag Münster, 2009.

2. Abukhalil, As'ad and Farid Esack. "The US, the Muslim World and an Islamic Response.” Policy Perspectives 5/1.

3. Afilalo, Ari and Dennis Patterson. "Statecraft, Trade and the Order of States." Chicago Journal of International Law 6/ 2 (Winter 2006).

4. Alazzany, Murad ali obaid Abdullah. "A Critical Discourse Analysis of the Representation of Islam and Muslims following the 9/11 events as reported in the New York Times." University putra Malaysia, November 2008, http://psasir.upm.edu.my/10335/1/FBMK_2008_23_A.pdf accessed 12 September 2013.

5. Ali, Dr. Zulifiqar. "Post-Modern Refutation of Faith and Religion: Exploring Foucault's Argument," Journal of Islamic Thought and Civilization 2/1 (Spring 2012).

6. Awan, Muhammad Safeer. "Global Terror and Rise of Xenophobia/Islamophobia: An Analysis of American Cultural Production since September 11." Islamic Studies 49/4 (winter 2010).

7. "Ask the Religion Experts: Is there a difference between faith and religion? The Ottawa Citizen, Canada 17 January 2013.

http://www.ottawacitizen.com/life/Religion+Experts+there+difference+between+fait h+religion/7833531/story.html\#ixzz2WP5a2PVI, accessed 26 September 2013.

8. Aziz, K.K. The Murder of History. Lahore: Vanguard Books Pvt Ltd, 1993.

9. Bahfen, Nasya. "Borderless Islam and the Modern Nation state." Intellectual Discourse 19 (2011): 147-160.

10. Bakhtiyar, Syed Shahjahan. "COMMENT: 'Unity, Faith, Discipline', a slogan or a way forward? Daily Times, 22 April 2013.

11. Brown, Katherine Butler. "Did Aurangzeb Ban Music? Questions for the Historiography of his reign." Modern Asian Studies 41/1:78.

12. Cavendish, Richard. "Caliph Uthman Murdered." History Today, 56/6 (June 2006).

13. Csicsmann, Dr. Laszlo. "Islamist Movements at the Crossroads: the Choice between Ideology and context-driven Approach to Politics. Case study on the Hashmite Kingdom of Jordan. " Journal of Islamic Thought and Civilization 1/ 2 (fall 2011).

14. Clarke, Abdassamad, "The Falsity of the Concept of the Islamic State," BW, http://www.bogvaerker.dk/Bookwright/state.html\#note-17fd0550, accessed 26 September.

15. Draper, John. "Why are Muslim countries poor?" 22 February 2013,

16. http://www.cobourgatheist.com/index.php/islam/muslim-culture/1016-why-aremuslim-countries-poor

17. Dworkin, Ronald. "Three Questions for America," The New York Review Books, 21 September 2006, http://www.nybooks.com/articles/archives/2006/sep/21/threequestions-for-america/?pagination=false, accessed 26 September 2013.

18. Eaton, Richard M. "Temple Desecration and Indo-Muslim States." Religions Sikhism: Guru Tegh Bahadur", BBC. 1 October 2009. http://www.bbc.co.uk/religion/religions/sikhism/people/teghbahadur.shtml

19. Enayat, Hamid. Modern Islamic Political Thought. Kuala Lumpur: Islamic Book Trust, 2001. 
20. Esmail, Aziz. "Reason and Religion: The Old Argument Revisited." Institute of Ismaili Studies 2003, accessed 26 September 2013, http://www.iis.ac.uk/SiteAssets/pdf/esmail_reason_religion.pdf

21. "Encyclopedia Britannica: reason and Rationalism," http://www.britannica.com/EBchecked/topic/493197/reason and http://www.britannica.com/EBchecked/topic/492034/rationalism, accessed 26 September 2013.

22. Fearly, Anthony Bubalo Greg. "Joining the caravan? The Middle East, Islamism and Indonesia." Lowy Institute Paper 05, 2005, The Lowy Institute for International Policy, Australia.

23. Feyyaz, Muhammad. "Radicalisation in Pakistan." Unpublished Paper 2013, UMT Lahore.

24. Feyyaz, Muhammad. "Facets of Religious Violence in Pakistan." Counter Terrorist Trends and Analysis 5/2 (2013).

25. Falahi, Ghulam Nabi. "Ijtihad - Question of the Controversy Regarding the Closing of the Gate of ijtihad." UK Islamic Mission, http://www.chsbs.cmich.edu/fattah/courses/pols426/ijtihad.pdf, accessed 16 September 2013

26. Fox, Jonathan. "Separation of Religion and State and Secularism in Theory and in Practice." Religion, State and Society 39:4 (2011).

27. Furnish, Timothy R. "Beheading in the Name of Islam", Middle East Quarterly (Spring 2005).

28. Ghazi, Mahmood Ahmad. State and Legislation in Islam. Islamabad: Publisher Sharia Academy International Islamic University, 2006.

29. Ghazi, Mahmood Ahmad, "The Islamic State in the Contemporary International Scenario," Policy Perspectives 4/2.

30. Ghamdi, Javed Ahmad. Islam: A Concise Introduction 1st Edition. Translated by Shehzad Saleem, Lahore: Mawrid, 2008.

31. Guppy, Shusha. "Caliphs of a Golden Age." Review of Heirs of the Prophet Muhammad, by Barnaby Rogerson, the Independent, 19 February 2006, http://www.independent.co.uk/arts-entertainment/books/reviews/heirs-of-theprophet-muhammad-by-barnaby-rogerson-525668.html.

32. Hallaq, Wael B. "Was the Gate of Ijtihad Closed? International Journal of Middle East Studies 16 (1984).

33. Hallaq, Wael B. The Impossible State: Islam, Politics, and Modernity's Moral Predicament. New York: Columbia University Press, 2012.

34. Haj, Samira. Reconfiguring Islamic Tradition: Reform, Rationality and Modernity. Stanford: Stanford University Press.

35. Helfstein, Scott. "The Rise of Sectarian Populism," The National Interests 18 July 2013.

36. Hussain, Asaf Hussain. "The Ideology of Orientalism.” In Orientalism, Islam, and Islamists edited by Asaf Hussain, Robert Olson and Jamil Qureshi. Battleboro Vermont: Amana Books, 1984.

37. Hussain, Riffat. "The Meaning and Role of Intuition in Iqbal's Philosophy". www.allamaiqbal.com, accessed 27 September 2013.

38. Iqbal, Muhammad. The Reconstruction of Religious Thought in Islam, ed. M. Saeed Sheikh. Lahore: Institute of Islamic Culture, 1996.

39. Iqbal, Muhammad. Zarbe-e-Kaleem. Lahore: Iqbal Academy Pakistan, n.d. 
40. Ismael, Tareq Y. and Jacqueline S. Ismael. Government and Politics in Islam. London: Frances Printer (Publishers), 1985.

41. Islahi, Amin. Fundamentals of Hadith Interpretation by Islahi (Mabadi Tadabbur-e Hadith). Translated by Tariq Hashmi 11 November 2009.

42. "Islam's Position on Extremism, Radicalism, and Terrorism," in Amman Message (Declaration 154), Jordan: 2006. http://www.ammanmessage.com/

43. Jan, Tarik. Is Islamic Governance Theocracy? - Pakistan between Secularism and Islam. Islamabad: Institute of Policy Studies, 1998.

44. Jeddah, Arab News Jeddah. Our Dialogue: the Religious Editor, MAS Media Karachi (n.d.).

45. Kazem Alamdari, "Religion and Development Revisited: Comparing Islam and Christianity with Reference to the Case of Iran," Journal of Developing Societies 20/ $1-2$.

46. Khalil, Ashraf. "What the Salafis Want: An Interview with the Blind Sheik's Son." Time September 2012.

47. Kennedy, Paul. The Rise and Fall of the Great Powers. Rawalpindi: Services Book Club, 1996.

48. Khatab, Sayed. The Political Thought of Sayyid Qutb: The Theory of Jahiliyyah. London and New York: Routledge 2006.

49. Mahmood, Sohail. The Concept of an Islamic State. Lahore: Progressive Publishers, 1989.

50. Maududi, Maulana Abul A'la. Khilafat-o-Malukiat. Edition 31. Lahore: Idara Tarjamnaul Quran, 2008 [1966]).

51. Mas, Ruth. "Qiy As: A Study in Islamic Logic.” Folia Orientalia 34 (1998), accessed 3 October 2013, http://spot.colorado.edu/ rmas/MasQiyas1998.pdf

52. Maududi, Maulana Abul A'la. Jihad in Islam. Translated by Abdul Waheed Khan. Accessed on 24 September 2013. http://www.scribd.com/doc/18996214/11-Jihad-inIslam-by-Maududi.

53. Moten, Abdul Rashid. Review of The Fall and Rise of the Islamic State, by Noah Feldman, Intellectual Discourse 17/1 (2009): 107-122.

54. Mukhia, Harbans. The Mughals of India. USA: Wiley, 2004.

55. "Muslim world's Condition”, Dawn.com, 5 Dec 2012.

56. Oba, Dr. Abdulmomini A. "Human Rights and Beyond: some Conceptual Differences between Islamic and Western Perspectives of Human Rights." Journal of Islamic Thought and Civilization, 2/1 (Fall 2012).

57. Pappas, Stephanie. "Belief in God Boils Down to a Gut Feeling", LiveScience 21 September 2011, accessed 26 September 2013.

58. Ping, Jonathan H. Middle Power Statecraft: Indonesia, Malaysia and the Asia Pacific. UK: Ashgate Publishing, Ltd., 2005.

59. Qadri, Tahir ul. Fatwa-Terrorism Fitna- Khawarij. ${ }^{\text {st }}$ Edition. Lahore: Minhaj Books, January 2010.

60. Racine, Jean-Luc. "Pakistan's Predicament: The Diagnostic and the Debates within," Journal of Pakistan Vision, 13/1 (2012).

61. Richards, John F. The Mughal Empire, The New Cambridge History of India 5 reprinted edition. UK: Cambridge University Press.

62. Sabet, Amr G. E. Islam and the Political Theory, Governance and International Relations. London: Pluto Press, 2008.

63. Sowa, John F. and Arun K. Majumdar. "Analogical Reasoning," http://www.jfsowa.com/pubs/analog.htm, accessed 3 October 2013. 
64. Sachedina, Dr. Abdulaziz. "Taqlid: Blind Adherence or Rational Acceptance?" Accessed 13 September 2013. http://people.virginia.edu/ aas/article/article5.htm

65. Sen, Amartya. The Idea of Justice. (Rawalpindi: Services Book Club, 2010).

66. Stocks, J. L.,"Reason and Intuition." in Reason and Intuition and Other Essays. London, 1939.

67. "Study Suggests Why Gut Instincts Work." LiveScience 8 February 2009.

68. Swindal, James. "Faith and Reason." Internet Encyclopedia of Philosophy, http://www.iep.utm.edu/faith-re/, accessed 27 September 2013.

69. The Beginnings of Shi'i Ijtihad, http://www.al-islam.org/al-tawhid/ijtihad/4.htm, accessed 10 September 2013.

70. "The Structure of Power in Iran," Iran Chamber Society, http://www.iranchamber.com/government/articles/structure_of_power.php\#sthash.V kzJ4RWJ.dpuf, accessed 3 October 2013.

71. Transparency International. "Corruption Perceptions Index 2012," http://www.transparency.org/cpi2012/results\#myAnchor1, accessed 13 September 2013.

72. Vaezi, Ahmed. Shi 'a Political Thought - Chapter 2- What is Wilayat al-Faqih? UK: Islamic Centre of England, 2004. Accessed 24 September. http://www.alislam.org/shiapoliticalthought

73. Vogel, Frank E. "The Closing of the Door of Ijtihad and Application of the Law." Paper delivered at the American Oriental Society Conference, Cambridge, Massachusetts, 13 March 1999. http://iepistemology.net/attachments/402_V10N3\%20FALL\%2093\%20-\%20Vogel\%20\%20The\%20Closing\%20Door\%20of\%20Ijtihad.pdf

74. Waqqas, Sad ibn Abu. "How door of Ijtihad was Closed? Islamic Voice 1206:138 (June 1998/ SAFAR 1419H).

75. Yazdi, Ayatullah Professor Muhammad Taqi Misbah. Islamic Political Theory (Statecraft) Volume 2. Iran: The Ahl al-Bayt ('a) World Assembly (ABWA), 2006.

76. Younus, Dr. Faheem. "Confronting Corruption in the Muslim World," Huff Post Religion, 16 June 2-11, http://www.huffingtonpost.com/faheem-younus/enforceshariah-law-or-le_b_877211.html, accessed 9 September 2013.

77. Zebiri, Kate. "The Redeployment of Orientalist Themes in Contemporary Islamophobia." Studies in Contemporary Islam 10/ 1-2 (2008). 